BEATA JACHIMCZAK

Uniwersytet im. Adama Mickiewicza

$w$ Poznaniu

\title{
KSZTAŁCENIE NAUCZYCIELI \\ DLA EDUKACJI WŁĄCZAJĄCEJ
}

\begin{abstract}
Aвsтract. Jachimczak Beata, Kształcenie nauczycieli dla edukacji właczającej [Teachers Education for Inclusive Education]. Studia Edukacyjne nr 48, 2018, Poznań 2018, pp. 33-43. Adam Mickiewicz University Press. ISSN 1233-6688. DOI: 10.14746/se.2018.48.3

Inclusive education as idea of education appeared in the 1990s. The main aim of inclusive education is full participation, opposition to exclusion of anyone from the possibility of education together with their peers, in their place of residence. It draws attention to the necessity to change the educational policy. In the inclusive education most important are needs (special needs) and oportunities of students, and support. One of the important conditions for the implementation of the idea is proper preparation of teachers for inclusive education. Analyzes of international experience indicate that there are similar problems in most countries. It is worth to recognize them, to take systemic action as soon as possible leading to the change of unfavorable indicators in Poland.
\end{abstract}

Key words: inclusive education, teachers education for inclusion

Edukacja włączająca to pojęcie, które w ostatnim czasie stało się terminem niezwykle popularnym, tak w odniesieniu do badań naukowych z dziedziny pedagogiki, jak i praktyki kształcenia.

Za początek myślenia o edukacji kategoriami włączania można uznać inicjatywę podjętą na Światowej Konferencji w Jomtien (Tajlandia 1990). Sformułowane wówczas hasło - „Edukacja dla wszystkich” - zostało przyjęte jako podstawa głównego programu edukacyjnego UNESCO, którego celem ustanowiono doprowadzenie do zaspokojenia podstawowych potrzeb edukacyjnych wszystkich ludzi. Światowa Deklaracja Edukacji dla Wszystkich ${ }^{1}$ przyjęta w 1990 roku w efekcie spotkania między innymi przed-

${ }^{1}$ World Declaration on Education for All: Framework for Action to Meet Basic Learning Needs, UNESCO, New York 1990. 
stawicieli 180 krajów (Banku Światowego, UNICEF) uznała za najpilniejszy cel zaspokojenie podstawowych potrzeb edukacyjnych, przez co rozumiano umiejętność czytania, pisania, liczenia, formułowania myśli, rozwiązywania problemów, ale również kształtowania postaw i wartości sprzyjających rozwojowi każdego człowieka. Szczególną uwagę zwrócono na problem zagrożenia wykluczeniem edukacyjnym (dziewcząt/kobiet, mniejszości narodowych, dzieci/osób z niepełnoprawnością, czy ubóstwo).

Kolejnym dokumentem istotnym dla promowania idei edukacji włączającej stała się Deklaracja z Salamanki (UNESCO, 1994)². Była ona efektem spotkania w Hiszpanii ponad 300 uczestników reprezentujących 92 rządy i 25 organizacji międzynarodowych, na którym wyrazili oni swoje poparcie dla zmian w polityce, niezbędnych dla promowania powszechnej edukacji. Hasło Edukacja dla Wszystkich miało odtąd stać się synonimem równości w dostępie do edukacji dla wszystkich dzieci i młodzieży, w szczególności ze specjalnymi potrzebami. Deklaracja w rzeczywistości stanowi zbiór zasad, wskazań dla polityki i praktyki oraz wytyczne do działań dla realizacji idei powszechnej edukacji, czyli takiej, która otwarta jest na każdego ucznia, poszanowanie indywidualnych różnic, wspieranie procesu uczenia się i uwzględnianie potrzeb uczniów. Pierwotna koncentracja na uczniach ze specjalnymi potrzebami edukacyjnymi była związana z dostrzeżeniem i sprzeciwem wobec praktyk wykluczania, marginalizowania edukacyjnego związanych z jakimkolwiek wymiarem odmiennego funkcjonowania człowieka. Panuje powszechna zgoda co do tego, że edukacja włączająca jest główną, jeśli nie jedyną, drogą realizacji kształcenia zgodnego $\mathrm{z}$ podstawowymi prawami jednostki ${ }^{3}$, a znajdującymi swoje źródła w takich dokumentach, jak: Powszechna Deklaracja Praw Człowieka ${ }^{4}$, Międzynarodowa Konwencja Praw Dziecka ${ }^{5}$, czy bardziej współczesnych, jak Konwencja o Prawach Osób Niepełnosprawnych ${ }^{6}$. Podnoszą one w pierwszej kolejności kwestie równego traktowania, praw przysługujących każde$\mathrm{mu}$, sprzeciwu wobec różnicowania, kategoryzowania ludzi z jakichkolwiek względów.

${ }^{2}$ UNESCO, The Salamanca Statement and framework for action on special needs education, Paris, France 1994.

${ }^{3}$ H. Savolainen i in., Understanding teachers' attitudes and self-efficacy in inclusive education: Implications for pre-service and in-service teacher education, European Journal of Special Needs Education, 2012, 27(1), s. 51-68.

${ }^{4}$ Powszechna Deklaracja Praw Człowieka, http://www.unesco.pl/fileadmin/user upload/pdf/Powszechna_Deklaracja_Praw_Czlowika.pdf [dostęp: 12.02.2013].

${ }^{5}$ Konwencja o prawach dziecka, przyjęta przez Zgromadzenie Ogólne ONZ 30 kwietnia 1991 r., DzU z 1991 r., nr 120, poz. 526.

${ }^{6}$ Konwencja Praw Osób Niepełnosprawnych ONZ Convention on the Rights of Persons with Disabilities, Unitet Nations New York: United Nations 2006, http://www.un.ogr/disabilities/ convention/conventionfull.shtml [dostęp: 20.05.2016]. 
Można zatem uznać, że początkiem działań związanych z edukacją włączającą musi być rozpoznanie zjawiska wykluczenia (exclusion) $)^{7}$. To z kolei możliwe będzie tylko wówczas, kiedy refleksja obejmie szeroki kontekst społeczny, nie tylko edukacyjny, zjawiska ${ }^{8}$. Konieczne wydaje się również ponowne zdefiniowanie źródeł uczenia się i zachowania, kształtowania się systemu wartości, czy wreszcie kulturowych kontekstów życia społecznego9. Wydaje się również, że edukacji włączającej nie da się zadekretować, bowiem jest to proces, który musi mieć swój początek w formalnych działaniach prawa oświatowego. Niemniej, jego sednem jest zmiana postaw społecznych, myślenie kategoriami włączania, równości, szacunku i tolerancji dla drugiego człowieka. Jest to trudny i powolny proces. Po ponad dwóch dekadach od momentu ukazania się Deklaracji, jak wskazuje Elizabeth Walton, wielu nauczycieli, ale również rodziców wciąż jeszcze nie jest w stanie wyobrazić sobie szkoły wolnej od stratyfikacji, zwłaszcza związanej z możliwościami uczniów ${ }^{10}$.

Definicja pojęcia edukacja włączająca nie jest tak łatwa, jak mogłoby się wydawać z semantycznego punktu widzenia. Zwłaszcza gdy zechcieć jej nadać wymiar międzynarodowy. Rozumienie terminu jest bowiem uwarunkowane różnicami kulturowymi, społeczno-ekonomicznymi, doświadczeniami związanymi $\mathrm{z}$ istniejącym modelem edukacji w poszczególnych krajach. Stąd, wciąż jeszcze w efekcie wskazanych uwarunkowań jest ona różnie odczytywana. Niektóre kraje wciąż jeszcze utożsamiają edukację włączającą z przygotowaniem szkolnictwa powszechnego (głównego nurtu - mainstream) na przyjęcie dzieci/uczniów z niepełnosprawnością. Jest to tak zwane wąskie rozumienie edukacji włączającej ${ }^{11}$, natomiast $\mathrm{w}$ rozumieniu nieco szerszym - edukacja otwarta na zróżnicowane potrzeby wszystkich uczniów nie tylko z poważnymi deficytami rozwojowymi. Najczęściej wówczas odnosi się ją do dzieci/uczniów ze specjalnymi potrzebami edukacyjnymi. W rozumieniu najszerszym jest to edukacja uwzględniająca potrzeby wszystkich uczniów, uczestników procesu kształcenia.

Ostatnia z perspektyw wydaje się najwłaściwsza, gdyż jest zgodna z ideą, z której wyrosło samo pojęcie, czyli sprzeciwu wobec negatywnego różnicowania, faworyzowania lub defaworyzowania. Paradoksem byłoby bowiem

${ }^{7}$ E. Walton, Dismantling the Empire of Educational Exclusion, [w:] Making Education Inclusive, red. E. Walton, S. Moonsamy, Cambridge 2015, s. 10.

${ }^{8}$ Contextualizing Inclusive Education. Evaluation Old and New International Perspectives, red.

D. Mitchell, London - New York 2005, s. 1.

9 Tamże, s. 4.

${ }_{10}$ Tamże, s. 13.

${ }^{11}$ T. Loreman, J. Deppeler, D. Harvey, Inclusive Education. A practical guide to supporting divesity in the classroom, London 2005. 
propagowanie tendencji, która miałaby w efekcie procesu poprawy sytuacji którejkolwiek grupy uczniów pogorszyć ją dla innej. Jest to jednocześnie najtrudniejsze rozwiązanie, gdyż zakłada konieczne skoncentrowanie się na potrzebach każdego ucznia - od wybitnie zdolnego, przez przeciętnego, po ujawniającego trudności w uczeniu się z jakiegokolwiek powodu. Potrzeby te, jak łatwo się domyślić, będą bardzo zróżnicowane i będą odnosić się do wszystkich obszarów funkcjonowania człowieka. Aby im sprostać, zmianie musi ulec myślenie o edukacji i szkole. Edukacja musi stać się jednym z priorytetów państwa i to rzeczywistym, a nie jedynie sztandarowym. Oznacza to zwiększenie nakładów na jej finansowanie, ale szeroko rozumiane - od wyposażania szkół (placówek) w najnowsze pomoce, przez zmianę programów kształcenia, tak by nie tyle przygotowywały do rzeczywistości, ale do przyszłości. To w niej bowiem będzie żył absolwent szkoły. W tym kontekście nie wolno zapominać o nauczycielach, a szczególnie o ich kształceniu, rekrutacji do zawodu i warunkach pracy oraz zatrudnienia.

Przyjmując zatem najszerszą perspektywę w definicji edukacji włączającej, można byłoby uznać, że jest to systemowe podejście do edukacji nastawione na dostosowanie wymagań edukacyjnych, warunków nauki i organizacji kształcenia do potrzeb i możliwości każdego ucznia, jako pełnoprawnego uczestnika procesu kształcenia. Celem edukacji włączającej powinno być wyposażenie uczniów w kompetencje niezbędne do budowania włączającego społeczeństwa, w którym osoby niezależnie od indywidualnych różnic są pełnoprawnymi członkami społeczności, a różnorodność z nich wynikająca postrzegana jest w kategoriach zasobów nie zaś ograniczeń.

Zrealizowanie takich założeń wymaga przygotowania kadr dla edukacji włączającej, które należy rozumieć szerzej niż tylko nauczycieli. Dotyczy to przygotowania zarówno przyszłych, jak i obecnych kadr. Nie ma bowiem wątpliwości, że niepokój wielu już pracujących nauczycieli, jak i dyrektorów placówek edukacyjnych względem edukacji włączającej stanowi do pewnego stopnia konsekwencję poczucia niekompetencji ${ }^{12}$ związanej z wejściem do szkół ogólnodostępnych w większym zakresie niż dotąd, i z większym zróżnicowaniem wewnętrznym, uczniów realizujących dotąd obowiązek kształcenia w szkołach specjalnych. Potęgowane są one dodatkowo innymi

${ }_{12}$ P. Westwood, Inclusive and adaptative teaching: Meeting the challenge of diversity in classroom, New York 2013; U. Bartnikowska, M. Wójcik, Zaniedbania w aspekcie triady: szkoła - rodzice - dziecko w kształceniu integracyjnym i masowym dzieci z wada stuchu, [w:] Watki zaniedbane, zaniechane, nieobecne w procesie edukacji i wsparcia spotecznego osób niepetnosprawnych, red. Z. Gajdzica, D. Osik-Chudowolska, Warszawa 2004; Z. Gajdzica, Nauczyciel edukacji wczesnoszkolnej w zreformowanej szkole powszechnej jako organizator procesu kształcenia dziecka upośledzonego umystowo w stopniu lekkim, [w:] Pedagogika specjalna w reformowanym ustroju edukacyjnym, red. Z. Palak, Lublin 2001. 
obawami, na przykład o finansowanie kształcenia, wsparcie nie tylko ucznia, ale i nauczyciela, adekwatność nakładu pracy do uposażenia (wciąż niskiego) kadry dydaktycznej.

\section{Kształcenie kadr}

Od początku dyskusji nad problemem wykluczenia edukacyjnego podkreślano, że celu programu Edukacji dla wszystkich nie da się zrealizować z pominięciem kształcenia i doskonalenia nauczycieli ${ }^{13}$. Z kolei Światowy raport o niepełnosprawności z 2011 roku, odnoszący się, jak wskazuje nazwa, w szczególności do jednej z grup osób zagrożonych wykluczeniem edukacyjnym, wskazuje na znaczenie właściwego kształcenia nauczycieli szkół ogólnodostępnych celem zapewnienia im poczucia kompetencji i wyposażenia w umiejętności niezbędne do nauczania grup uczniów o zróżnicowanych potrzebach. Warto zwrócić uwagę, jak wskazują autorzy raportu, że konieczne jest wyraźne ukierunkowanie kształcenia nauczycieli na postawy i wartości, a nie jedynie na umiejętności i wiedzę ${ }^{14}$. Równie ważne bowiem jak kształtowanie kompetencji praktycznych przyszłych kadr dla edukacji jest rozwijanie kompetencji kierunkowych związanych z postawami tolerancji, zrozumienia natury problemów społecznych leżących u podstaw wszelkich procesów marginalizacji i wykluczenia. W tym kontekście warto, jak myślę, wspomnieć o toczących się w ostatnim czasie $\mathrm{w}$ Polsce dyskusjach nad powiązaniem kształcenia nauczycieli z profilem praktycznym i ewentualnym odejściem od profilu ogólnoakademickiego. Profil praktyczny nastawiony jest na kształtowanie kompetencji stricte zawodowych. Pociąga to za sobą określony dobór kadry akademickiej, która miałaby się rekrutować z grona czynnych nauczycieli, zakorzenionych w praktyce szkolnej, w znacznie mniejszym stopniu z teoretyków, pracowników naukowych, badaczy, w tym przedstawicieli dyscyplin naukowych z obszaru nauk społecznych czy humanistycznych (np. socjologów, psychologów, filozofów). Czy jednak najlepsze, nawet najbardziej specjalistyczne kompetencje praktyczne nauczycieli będą wystarczające dla sukcesu działań włączających? W społeczeństwie opartym na wiedzy rola nauczyciela zmienia się. Przestaje on być skarbnicą wiedzy, stając się bardziej organizatorem procesu nauczania, twórcą sytuacji sprzyjających uczeniu się, doradcą uczniów, ich parterem i mediatorem pomiędzy nimi a różnymi nowoczesnymi źródłami informacji ${ }^{15}$.

${ }^{13}$ World Declaration on Education for All.

${ }^{14}$ World Report on Disability, WHO, Geneva 2011, s. 222.

${ }^{15}$ Europejska Agencja Rozwoju Edukacji Uczniów ze Specjalnymi Potrzebami, Ksztatcenie nauczycieli przygotowujace do edukacji wtaczającej - wyzwania i szanse, Europejska Agencja Rozwoju Edukacji Uczniów ze Specjalnymi Potrzebami, Odense, Dania 2011, s. 21. 


\section{Rekrutacja na studia nauczycielskie}

Jak wynika z danych Europejskiej Agencji Rozwoju Edukacji Uczniów ze Specjalnymi Potrzebami, we wszystkich krajach ${ }^{16}$ od kandydatów na nauczycieli wymaga się odpowiednio wysokich wyników końcowych na świadectwie szkoły ponadgimnazjalnej (średniej) ${ }^{17}$. Tymczasem, jak wskazują analizy NIK ${ }^{18}$, w Polsce $\mathrm{w}$ wypadku rekrutacji na studia (kierunki, specjalności nauczycielskie) zaczyna coraz wyraźniej zarysowywać się zjawisko „negatywnej selekcji”. Analizy NIK wskazują, iż ponad 9\% osób przyjętych na kierunki, specjalności nauczycielskie w latach 2014/2015 to absolwenci szkół ponadgimnazjalnych, którzy na egzaminie maturalnym uzyskali najniższe wyniki (tj. od 30 do 49 pkt.). Trudno stwierdzić, czy tak zróżnicowane wnioski są efektem przyjęcia innej metodologii badań czy ich prezentacji. Myślę, że każdy wykładowca akademicki mający styczność $z$ kształceniem na kierunkach nauczycielskich ma własne refleksje na ten temat. Z drugiej strony, jak potwierdzają analizy, nie ma żadnych gwarancji, że studenci osiągający najlepsze wyniki w nauce staną się najskuteczniejszymi nauczycielami ${ }^{19}$.

Nie ma jednak wątpliwości, że najlepsze systemy edukacyjne na świecie wyróżnia nie tylko wysoka jakość kształcenia nauczycieli, ale właśnie dbałość o pozyskanie najlepszych absolwentów szkół średnich na kandydatów do zawodu i dalej najlepszych absolwentów studiów do pracy w zawodzie ${ }^{20}$. To jednak związane jest z zapewnieniem im doskonałych warunków pracy, co ma miejsce w nielicznych krajach.

Naiwnością byłoby oczekiwać, że zawód nauczyciela wybiorą jedynie najlepsi absolwenci szkół średnich, jeśli w perspektywie mogą spodziewać się, jak to ma miejsce w Polsce, niewielkich poborów, trudnych warunków pracy, niskiego prestiżu społecznego profesji. Mimo tego, nieuprawnionym uproszczeniem, a jednocześnie krzywdzące byłoby z kolei generalizowanie, iż tylko te kwestie decydują o wyborze zawodu nauczyciela. Wielu jest w Polsce doskonałych, pełnych pasji nauczycieli, o wysokich kompetencjch, doskonalących się i nie wyobrażających sobie pracy innej niż z dziećmi i młodzieżą.

16 W tym w Polsce, tamże, s. 107.

17 Tamże s. 23.

18 Przygotowanie do wykonywania zawodu nauczyciela. Informacja o wynikach kontroli, Departament Nauki, Oświaty i Dziedzictwa Narodowego, NIK, s. 6-7 https://www.nik.gov. pl/aktualnosci/nik-o-przygotowaniu-do-zawodu-nauczyciela.html [dostęp: 12.03.2018].

19 Europejska Agencja, s. 23.

${ }^{20}$ McKinsey and Company, Jak najlepiej doskonalone systemy szkolne na świecie stają się jeszcze lepsze, wyd. polskie, CEO 2007. 


\section{Kształcenie nauczycieli a problematyka edukacji włączającej}

W przypadku kształcenia przyszłych kadr dla edukacji, zdaniem UNESCO konieczna jest taka zmiana programów studiów, która zapewni realizacje problematyki koncentrującej się na szeroko rozumianym zagadnieniu edukacji włączającej. Z jednej strony dotyczyć to powinno problematyki specjalnych potrzeb edukacyjnych, w tym niepełnosprawności, ale również wiedzy i kompetencji odnoszących się do problematyki skutecznego wsparcia każdego ucznia i umiejętności pracy w zespole zróżnicowanym²1. Jeśli edukacja włączająca ma w założeniu koncentrować się na: dostosowaniu wymagań edukacyjnych, warunków nauki i organizacji kształcenia do potrzeb uczestnika procesu kształcenia w całożyciowej edukacji wraz z procesem kształcenia zawodowego, wejścia i uczestnictwa w rynku pracy, kadra odpowiedzialna za ten proces musi zostać przygotowana do jego realizacji w każdym wymiarze.

Raport Europejskiej Agencji Rozwoju Edukacji Uczniów ze Specjalnymi Potrzebami Edukacyjnymi dotyczący kształcenia nauczycieli przygotowywanych do edukacji włączającej wskazuje, iż różne są rozwiązania dotyczące treści kształcenia na kierunkach nauczycielskich. W niektórych krajach określa je ustawa, w innych ustawowo zapisano jedynie obszary kompetencji, a szczegóły wyboru zawartości programów pozostawiono poszczególnym uczelniom. Bywa wreszcie i tak, że państwo w ogóle nie ingeruje w zawartość programów akademickich. Z tego powodu są one trudne do porównania ${ }^{22}$. Jeśli chodzi o kształcenie nauczycieli w dziedzinie problematyki edukacji włączającej, doświadczenia w tym zakresie w krajach europejskich również są różne. Istnieje jednak dość powszechne przekonanie, iż wyposażenie nauczycieli w powyższe kompetencje nie jest możliwe bez zwiększenia liczby dodatkowych zajęć, czy dołożenia treści programowych. Z analiz przeprowadzonych na podstawie 29 raportów nadesłanych przez poszczególne kraje wynika, że mniej niż 10\% z nich oferuje specjalizację w zakresie specjalnych potrzeb edukacyjnych (SPE) na początkowym etapie ${ }^{23} \mathrm{kształce-}$ nia nauczycieli. W większości przypadków w ramach niektórych przedmiotów wprowadza się jednak zagadnienia związane z zaspokajaniem zróżnicowanych potrzeb uczniów. Jednak między sobą różnią się one bardzo. Niektóre skupiają się głównie na SPE i niepełnosprawności, inne zaś na różnorodnych potrzebach, w odniesieniu do wszystkich uczniów. Nakłada się na to różna terminologia w zakresie kluczowego pojęcia (np. w Danii ter-

21 UNESCO-IBE, Conclusions and recommendations of the 48th session of the International Conference on Education (ED/BIE/CONFINTED 48/5) Geneva 2008.

${ }^{22}$ Europejska Agencja, s. 25-26.

${ }^{23}$ Początkowy etap kształcenia to studia licencjackie. 
min edukacja włączająca nie jest obecny, stosuje się natomiast określenie zróżnicowanie uczniów), stąd obraz sytuacji w ramach kształcenia nauczycieli do edukacji włączającej nie rysuje się jasno. Z raportów krajowych wynika również, iż treści kursów w zakresie specjalnych potrzeb czy szerzej edukacji włączającej dobierane są dość przypadkowo i rzadko kiedy są powiązane z innymi obszarami kształcenia. Czas przeznaczony na kursy związane z edukacją włączającą również jest zróżnicowany w zależności od kraju - od 1-2 modułów do dłuższych kursów, które stanowią nawet obowiązkowy element programów studiów. Na przykład, w Szwajcarii uznaje się, że treści dotyczące podstawowych zagadnień w zakresie specjalnych potrzeb, zróżnicowanych potrzeb uczniów, praktyki pracy zespołowej, rozwoju szkoły oraz jej zmian organizacyjnych w kierunku placówki włączającej, powinny stanowić $5 \%$ programów studiów dla nauczycieli szkół podstawowych i ponadpodstawowych ${ }^{24}$. Z kolei w Austrii pojęcie edukacja włączająca obecne jest $\mathrm{w}$ programach jedynie czterech uczelni, niemniej większość instytucji kształcących nauczycieli uwzględnia w programach tematykę różnorodności, edukacji włączającej, indywidualizacji pracy z uczniem, promocji uzdolnień uczniów, czy metod pracy opartych na metodzie projektu ${ }^{25}$.

Częściej treści związane z przygotowaniem do pracy w ramach edukacji włączającej pojawiają się w programach studiów z dziedziny edukacji wczesnoszkolnej, niż kształcenia nauczycieli szkół ponadpodstawowych. Kształcenie dedykowane problematyce edukacji włączającej w postaci osobnych modułów należy do rzadkości. Ma to miejsce na przykład w 50\% uczelni niemieckich kształcących w zakresie wczesnej edukacji. Około 30\% uczelni prowadzących studia pedagogiczne na Litwie ma w swoich programach treści związane z problematyką specjalnych potrzeb edukacyjnych i/lub edukacji włączającej. W niektórych krajach, na przykład w Danii, tematyka zróżnicowanych grup uczniów nadal omawiana jest w ramach programów z pedagogiki specjalnej, a nie programów skierowanych na przyszłych nauczycieli szkół ogólnodostępnych. Autorzy większości raportów krajowych stoją na stanowisku, że dodanie tematyki edukacji włączającej do wszystkich programów studiów może nieść ze sobą niebezpieczeństwo przypadkowego doboru tematyki, a w efekcie ograniczonej skuteczności ukształtowanych w ten sposób kompetencji. Z doświadczeń hiszpańskich wynika z kolei, że programy nauczania poświęcone problematyce edukacji włączającej są zazwyczaj skoncentrowane na problematyce edukacji uczniów ze specjalnymi potrzebami i integracji uczniów ze SPE w szkołach, nie zaś na szeroko rozumianym problemie zróżnicowanych potrzeb wszystkich uczniów ${ }^{26}$.

\footnotetext{
${ }^{24}$ Europejska Agencja, s. 28.

25 Tamże, s. 30.

${ }^{26}$ Tamże, s. 25-26.
} 
Celem sprawdzenia, jak przedstawia się kwestia przygotowania kadr do edukacji włączającej w Polsce dokonałam krótkiego przeglądu ofert kształcenia w publicznych uczelniach wyższych o typie uniwersytetu. Co prawda publikacja Europejskiej Agencji Rozwoju Edukacji Uczniów ze Specjalnymi Potrzebami Edukacyjnymi, na który się powoływałam, w analizach uwzględnia dane z Polski, nie ma jednak do nich dostępu, nie były one również cytowane w żadnym z przykładów rozwiązań.

Skorzystałam z wykazu uczelni wyższych zamieszczonego na stronie internetowej Ministerstwa Nauki i Szkolnictwa Wyższego ${ }^{27}$, a następnie z oficjalnych stron wszystkich publicznych uniwersytetów w Polsce (linkowanych na stronie MNiSW). Z analiz tych wynika, że spośród 18 publicznych uniwersytetów jedynie na 4 (22\%) w ofercie kształcenia są specjalności odnoszące się do problematyki edukacji włączającej. Obecne są one na:

- Uniwersytecie Warszawskim w ofercie jest specjalność: Integracja i inkluzja społeczno-edukacyjna (studia II stopnia, kierunek pedagogika);

- Uniwersytecie im. Adama Mickiewicza w Poznaniu: Pedagogika wspierająca uczniów ze specjalnymi potrzebami edukacyjnymi (studia I i II stopnia, kierunek pedagogika specjalna);

- Uniwersytecie Kardynała Stefana Wyszyńskiego: Edukacja włączajaca i integracyjna uczniów ze specjalnymi potrzebami edukacyjnymi (studia I stopnia, kierunek pedagogika specjalna), Terapia pedagogiczna z edukacja właczająca (studia II stopnia, kierunek pedagogika specjalna), Edukacja przedszkolna i wczesnoszkolna z edukacja wtaczająca (studia II stopnia, kierunek pedagogika);

- Uniwersytet Zielonogórski: Rewalidacja i terapia pedagogiczna uczniów ze specjalnymi potrzebami edukacyjnymi (studia I stopnia, kierunek pedagogika specjalna).

W każdym przypadku specjalności te realizowane są na kierunku pedagogika lub pedagogika specjalna, tym samym jeśli nadają kwalifikacje nauczycielskie dotyczą one wczesnej edukacji (przedszkolnej i wczesnoszkolnej). Zatem, z polskich doświadczeń wyłania się problem, z którym boryka się również większość krajów UE; jeśli edukacja włączająca pojawia się jako specjalność nauczycielska to $\mathrm{w}$ ramach edukacji małego dziecka.

Niestety, powielamy również schemat obserwowany w innych krajach. Kształcenie $\mathrm{w}$ dziedzinie edukacji włączającej ukierunkowane jest na problematykę specjalnych potrzeb edukacyjnych i/lub niepełnosprawności. Brakuje w programach kształcenia w zakresie edukacji włączającej spojrzenia szerszego, wychodzącego poza deficyty i zaburzenia rozwoju. Nie pojawia się praktycznie problematyka odnoszona do pracy w grupie zróżnicowanej, rzadko

${ }^{27}$ www.nauka.gov.pl zakładka uczelnie - wykazy, uczelnie publiczne, uniwersytety [dostęp: 25.04.2018]. 
w ramach specjalności tych obecne są zagadnienia dotyczące wybitnych zdolności, mniejszości kulturowych (wyznaniowych). Obydwa te zagadnienia pojawiają się sporadycznie i najczęściej separacyjnie $w$ ramach kolejnych specjalności, wówczas jednak w programach nie ma treści związanych z innymi specjalnymi potrzebami edukacyjnymi, w tym z niepełnosprawnością.

Kolejnym problemem jest przygotowanie z dziedziny edukacji włączającej nauczycieli przedmiotów, tak w ramach edukacji podstawowej, jak i ponadpodstawowej. Problematyka jest praktycznie nieobecna, i nie jest tu mowa o jakimkolwiek bloku treści, nie ma nawet pojedynczych modułów (przedmiotów kształcenia) w minimalnym wymiarze godzinowym. Przyszli nauczyciele, na przykład historii, matematyki, czy chemii $\mathrm{w}$ Polsce nie przechodzą zazwyczaj nawet podstawowego kursu z dziedziny pedagogiki specjalnej. Trudno sobie wyobrazić ich jako skutecznie współpracujących z uczniem ze specjalnymi potrzebami edukacyjnymi, jako wspierających, dostosowujących wymagania edukacyjne (program, treści kształcenia), warunki nauki, warunki organizacyjne kształcenia do ich potrzeb i możliwości.

Z doświadczeń nie tylko kształcenia w naszym kraju wynika, że prawdopodobnie trudno będzie $w$ wymiarze godzinowym obecnych programów kształcenia zmieścić dodatkowe treści związane z problematyką edukacji włączającej. Być może warto zatem uświadomić sobie, iż zmiany w tym zakresie będą musiały nastąpić, jeśli oczywiście w założeniu edukacja włączająca ma być w Polsce realizowana, a nauczyciele mają zyskać podstawowe choćby w tym zakresie kompetencje. One wystarczą jednak tylko, by rozpocząć pracę z uczniem; następnie trzeba je będzie uzupełniać w procesie doskonalenia zawodowego, na przykład w postaci studiów podyplomowych kwalifikacyjnych, kursów lub szkoleń doskonalących.

Ostatnia już kwestia, na którą warto zwrócić uwagę w ramach tytułowego zagadnienia, związana jest z przygotowaniem kadr zarządzających i nadzorujących oświatę, edukację. Mowa tu jest o dyrektorach szkól, placówek oświatowych, ale również pracownikach instytucji, którym są one podległe: wydziały edukacji, kuratoria oświaty i wychowania. Zmiana myślenia o edukacji, jako edukacji dla wszystkich, wymaga zrozumienia uwarunkowań edukacji włączającej w ramach polityki oświatowej. Jedynie sprzyjające, rozumiejące, a wypływające $\mathrm{z}$ wiedzy na temat zagadnienia, postawy osób zarządzających edukacją są szansą na rzeczywistą realizację idei. Wspieranie nauczycieli i szkół w tworzeniu warunków, w których wspólna edukacja uczniów będzie korzystnym rozwiązaniem dla każdego ucznia wymaga zrozumienia złożonych uwarunkowań procesu, zróżnicowania potrzeb szkól, placówek edukacyjnych, zależnie od tego, jakie są w danym momencie potrzeby. Jest to nastawienie, umiejętność i chęć takiej interpretacji zapisów 
prawa, by maksymalnie ułatwiać, wspierać, a w efekcie zachęcać każdą placówkę do podjęcia działań włączających.

\section{BIBLIOGRAFIA}

Bartnikowska U., Wójcik M., Zaniedbania w aspekcie triady: szkoła - rodzice - dziecko w ksztatceniu integracyjnym i masowym dzieci z wada stuchu, [w:] Wattki zaniedbane, zaniechane, nieobecne w procesie edukacji i wsparcia społecznego osób niepetnosprawnych, red. Z. Gajdzica, D. Osik-Chudowolska, Wydawnictwo Akademickie Żak, Warszawa 2004.

Contextualizing Inclusive Education. Evaluation Old and New International Perspectives, red. D. Mitchell, Routledge, London - New York 2005.

Europejska Agencja Rozwoju Edukacji Uczniów ze Specjalnymi Potrzebami, Kształcenie nauczycieli przygotowujace do edukacji właczajacej - wyzwania i szanse, Europejska Agencja Rozwoju Edukacji Uczniów ze Specjalnymi Potrzebami, Odense, Dania 2011.

Gajdzica Z., Nauczyciel edukacji wczesnoszkolnej w zreformowanej szkole powszechnej jako organizator procesu ksztatcenia dziecka upośledzonego umystowo w stopniu lekkim, [w:] Pedagogika specjalna w reformowanym ustroju edukacyjnym, red. Z. Palak, Wydawnictwo UMCS, Lublin 2001.

Konwencja o prawach dziecka, przyjęta przez Zgromadzenie Ogólne ONZ 30 kwietnia 1991 r., DzU z 1991 r., nr 120, poz. 526.

Konwencja Praw Osób Niepetnosprawnych ONZ, Convention on the Rights of Persons with Disabilities, Unitet Nations New York: United Nations 2006, http://www.un.ogr/disabilities/convention/conventionfull.shtml [dostęp: 20.05.2016].

Loreman T., Deppeler J., Harvey D., Inclusive Education. A practical guide to supporting divesity in the classroom, Routledge, London 2005.

McKinsey and Company, Jak najlepiej doskonalone systemy szkolne na świecie stają się jeszcze lepsze, wyd. polskie, CEO 2007.

Powszechna Deklaracja Praw Człowieka, http://www.unesco.pl/fileadmin/user_upload/ pdf/Powszechna_Deklaracja_Praw_Czlowika.pdf [dostęp: 12.02.2013].

Przygotowanie do wykonywania zawodu nauczyciela. Informacja o wynikach kontroli, Departament Nauki, Oświaty i Dziedzictwa Narodowego, NIK, s. 6-7 https:/ / www.nik.gov. $\mathrm{pl} /$ aktualnosci/nik-o-przygotowaniu-do-zawodu-nauczyciela.html

Savolainen H., Engelbrecht P., Nel M., Malinen O.P., Understanding teachers' attitudes and self-efficacy in inclusive education: Implications for pre-service and in-service teacher education, European Journal of Special Needs Education, 2012, 27(1).

UNESCO-IBE, Conclusions and recommendations of the 48th session of the International Conference on Education (ED/BIE/CONFINTED 48/5) Geneva 2008, UNESCO IBE.

UNESCO, The Salamanca Statement and framework for action on special needs education, Paris, France 1994.

Walton E., Dismantling the Empire of Educational Exclusion, [w:] Making Education Inclusive, red. E. Walton, S. Moonsamy, Scholars Publishing, Cambridge 2015.

Westwood P., Inclusive and adaptative teaching: Meeting the challenge of diversity in classroom, Routledge, New York 2013.

World Declaration on Education for All: Framework for Action to Meet Basic Learning Needs, UNESCO, New York 1990.

World Report on Disability, WHO, Geneva 2011.

www.nauka.gov.pl zakładka uczelnie - wykazy, uczelnie publiczne, uniwersytety 